\title{
Bcl-2 prevents activation of CPP32 cysteine protease and cleavage of poly (ADP-ribose) polymerase and U1-70 kD proteins in staurosporine-mediated apoptosis
}

\author{
Sandrine Estoppey ${ }^{1}$, Ivan Rodriguez ${ }^{1,2}$, Rémy Sadoul ${ }^{1}$ and \\ Jean-Claude Martinou ${ }^{1,3}$ \\ ${ }^{1}$ Glaxo Insititute for Molecular Biology, 14 chemin des Aulx, Plan-Les Ouates, \\ Switzerland \\ 2 Centre Médical Universitaire, Dept of Pathology, Geneva $\mathrm{CH}$ \\ ${ }^{3}$ corresponding author: Jean-Claude Martinou, Glaxo Institute for Molecular \\ Biology, 14, chemin des Aulx, 1228 Plan-Les-Ouates Geneva, CH \\ tel: 22706 9822; fax: 227946965 Email: JCM26619 GGR. CO.UK
}

Received 12.4.96; revised 7.6.96; accepted 10.6.96

Edited by M.L. Gougeon

\begin{abstract}
Members of the the Bcl-2 and ICE/ced-3 gene families have been implicated as essential components in the control of the cell death pathway. Bcl-2 overexpression can prevent programmed cell death (PCD) in different cell types. ICE/ced3-like proteases are synthesized as pro-enzymes and are activated by limited proteolysis. When overexpressed in diverse cell types, they trigger PCD. Bcl-2 can inhibit PCD mediated by these proteases, although as yet it is not clear at what specific step in the cell death pathway the protein acts. Here, we demonstrate that CPP32/Yama/Apopain, a member of the ICE/Ced-3 gene family, is processed during staurosporineinduced apoptosis in HeLa cells and that concomitant with CPP32 activation, two other proteins, poly (ADP-ribose) polymerase (PARP) and the U1-70 K small ribonucleoprotein, also undergo proteolysis. Overexpression of $\mathrm{Bcl}-2$ prevents cleavage of CPP32, PARP and U1-70 K and protects HeLa cells from PCD. These results demonstrate that Bcl-2 controls PCD, by acting upstream of CPP32/Yama/Apopain.
\end{abstract}

Keywords: apoptosis, CPP32, proteases, Bcl-2, staurosporine, poly (ADP ribose) polymerase, $\mathrm{U} 1-70 \mathrm{~K}$ ribonucleoprotein

Abbreviations: $\mathrm{PCD}$, programmed cell death; PARP, poly (ADP-ribose) polymerase; ICE, interleukin $1 \beta$ converting enzyme; U1-70K, U1 small nuclear ribonucleoprotein

\section{Introduction}

Programmed cell death (PCD) is a form of active cell death that occurs in many cell types during development and in pathology. PCD can occur in response to a variety of stimuli and is mediated through multiple pathways which are as yet poorly understood. Genetic studies on the nematode
C. elegans have identified two genes, ced-3 and ced-4, which are major components of the cell death program (Ellis et al, 1991). Ced-9 shows structural homology with proteins of the Bcl-2 family (for a review see Reed, 1994), whereas ced-3 is homologous to IL-1 $\beta$ converting enzyme (ICE) (Kumar and Harvey, 1995; Yuan, 1995). Members of the Bcl-2 family can be subdivided in two subgroups according to whether they display anti-apoptotic or pro-apoptotic function. Interaction between these proteins constitutes a checkpoint (Oltvai and Korsmeyer, 1994) in the cascade of events that lead to PCD although at present the mechanism of action of these proteins is unknown. Cysteine proteases of the ICE family which currently includes CPP32/Yama/Apopain (FernandesAlnemri et al, 1994; Tewari et al, 1995; Nicholson et al, 1995), Nedd-2/lch-1 (Kumar al, 1994; Wang et al, 1994), TX/ Ich-2/ICEII (Munday et al, 1995; Faucheu et al, 1995; Kamens et al, 1995), ICE-rel-III (Munday et al, 1995), Mch2 (Fernandes-Alnemri et al, 1995) and ICE-LAP3 (Duan et al, 1996). These proteases are synthesized as proenzymes and are activated by cleavage of a $\mathrm{N}$-terminal sequence and removal of an internal peptide thus generating two subunits of approximately 20 and $10 \mathrm{Kd}$. This was demonstrated for ICE and probably applies to all proteases of this family. The protease(s) responsible for this cleavage is unknown, although activation by autoprocessing is one possibility. Several members of the ICE family have been shown, in vitro, to cleave poly(ADP ribose) polymerase (PARP), a nuclear enzyme involved in DNA repair and control of genome integrity (Kaufmann et al, 1993, Lazebnik et al, 1994). In addition to PARP, ICE-like proteases are likely to have several other substrates including the $70 \mathrm{kD}$ protein component of the U1 small nuclear ribonucleoprotein (U170K) (Casciola-Rosen et al, 1994), lamins, topoisomerase I (Martin and Green, 1995), and sterol regulatory elementbinding protein-1 (Wang et al, 1995). Cleavage of these proteins appears to be an early event of PCD as it occurs well before any morphological signs of cell demise. All the proteases of the ICE family have been shown to induce PCD in several cell types and this effect can be blocked by coexpression of Bcl-2 (Kumar et al, 1994; Wang et al, 1994; Miura et al, 1993). Two viral proteins, CrmA and p35 from cowpoxvirus and baculovirus respectively are potent inhibitors of the catalytic activity of ICE-like (Xue and Horvitz, 1995; Bump et al, 1995). However, the mechanism by which Bcl-2 inhibits the killing function of these proteases is unknown. Here, we have investigated whether activation of CPP32 occurs during PCD and whether $\mathrm{Bcl}-2$ can interfere with this process. These studies were performed in the well characterized model system of staurosporine-induced apoptosis (Jacobson et al, 1993, 1994). We report that, in HeLa cells undergoing staurosporine-triggered apoptosis, CPP32 is 
activated by cleavage and that overexpression of $\mathrm{Bcl}-2$ prevents cleavage of CPP32 and protects cells. These results demonstrate that, in this model of $\mathrm{PCD}, \mathrm{Bcl}-2$ acts before activation of CPP32.

\section{Results and Discussion}

\section{Bcl-2 inhibits programmed cell death induced by staurosporine in Hela cells}

Staurosporine has been shown previously to trigger apoptosis in different cell types. This compound was tested on Hela cells expressing either endogenous levels of $\mathrm{Bcl}-2$ (control cells) or stably transfected with an expression vector which drives overexpression of $\mathrm{Bcl}-2$. These latter cells contain about three times more $\mathrm{Bcl}-2$ than control cells based on Western blot analysis (Figure 1). Control and $\mathrm{Bcl}-2$ overexpressing cells were treated with $1 \mu \mathrm{M}$ staurosporine and cell survival was measured at different times after addition of the compound. Counting of condensed nuclei after Hoechst labeling was used to quantify cell death. We found that approximately $50 \%$ of control cells underwent apoptosis within $24 \mathrm{~h}$ following addition of staurosporine (Figure 2). In contrast, cells overexpressing $\mathrm{Bcl}-2$ were more resistant to the compound and less than $10 \%$ of them died during the same period. These data are in agreement with those previously published by Jacobson et al (1993, 1994).

\section{Bcl-2 prevents cleavage of CPP32 induced by staurosporine treatment}

Cleavage of CPP32 was analyzed by Western blotting in cell extracts from control and $\mathrm{Bcl}-2$-overexpressing cells (Figure $3 \mathrm{~A}$ and $\mathrm{B})$. A monoclonal antibody directed against p20 of

A

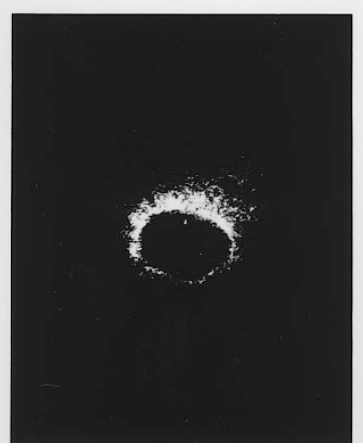

B
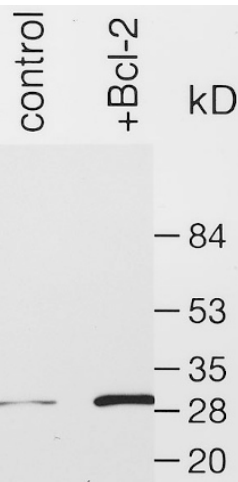

Figure 1 Hela cells overexpressing Bcl-2. (A) Immunofluorescence analysis of $\mathrm{Bcl}-2$ in $\mathrm{HeLa}$ cells overexpressing Bcl-2. (No staining was detectable in untransfected cells (not shown). (B) Immunoblotting analysis of $\mathrm{Bcl}-2$ in control and $\mathrm{Bcl}-2$ overexpressing cells. HeLa cells were stably transfected with a plasmid vector encoding human $\mathrm{Bcl}-2$. Levels of $\mathrm{Bcl}-2$ were quantified by immunoblotting in pools of cells overexpressing $\mathrm{Bcl}-2$ and in HeLa cells transfected with an empty vector (control cells). Note that Bcl-2-overexpressing cells contain about three times more Bcl-2 than control cells.
CPP32 recognized a band of about $30 \mathrm{kD}$ which corresponds to full length CPP32. Following a $15 \mathrm{~h}$ exposure to staurosporine, the intensity of this band slightly decreased in control cells with concomitant appearance of a lower molecular weight band of about $20 \mathrm{kD}$. This band, which probably corresponds to the $\mathrm{p} 17$ subunit of CPP32, was first detected $2 \mathrm{~h}$ after addition of staurosporine to the cells and its intensity peaked $15 \mathrm{~h}$ later (Figure $3 \mathrm{~A}$ ). As expected the antibody used in these experiments did not detect the p12 subunit of CPP32. The cleavage of CPP32 preceded appearance of apoptotic cells (cf. Figure 2) suggesting that CPP32 activation might take part in the cell death process, rather than just being a consequence of it. In contrast, in Bcl-2 overexpressing cells, the cleavage of CPP32 did not occur (Figure 3B). The intensity of the band corresponding to p32 remained almost constant for $24 \mathrm{~h}$ and no $17 \mathrm{kD}$ band was detected. These results demonstrate that $\mathrm{Bcl}-2$ prevents cleavage of CPP32.

\section{Bcl-2 prevents cleavage of PARP and U1-70 kD in staurosporine-treated HeLa cells}

CPP32 has been previously shown, in vitro, to cleave PARP into a fragment of $85 \mathrm{kD}$ that is retrieved in apoptotic cell extracts (Tewari et al, 1995; Nicholson et al, 1995). We therefore analyzed by immunoblotting the cleavage of PARP in control and $\mathrm{Bcl}-2$-overexpressing cells using an antibody that was kindly provided by $\mathrm{G}$. De Murcia. In cell extracts from untreated control and $\mathrm{Bcl}-2$ overexpressing cells, we detected a $116 \mathrm{kD}$ band which corresponds to intact PARP (Figure 3A and $B$ ). In addition, this antibody detected a faint band running

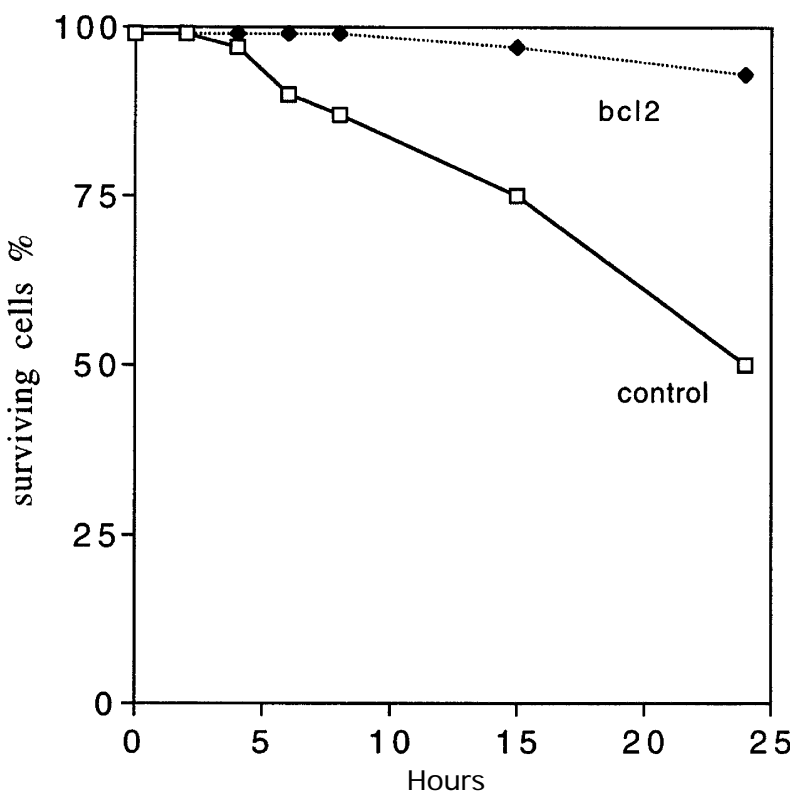

Figure 2 Effects of staurosporine on survival of control and $\mathrm{Bcl}-2$ overexpressing HeLa cells. HeLa cells were plated in Petri dishes and grown in DMEM medium containing $10 \%$ FCS. Staurosporine was added at a concentration of $1 \mu \mathrm{M}$ and cell survival analysed at different times after addition of the compound as described in (in Jacobson et al, 1993, 1994). The results represent the number of apoptotic nuclei determined by Hoechst staining and are representative of three different experiments. 


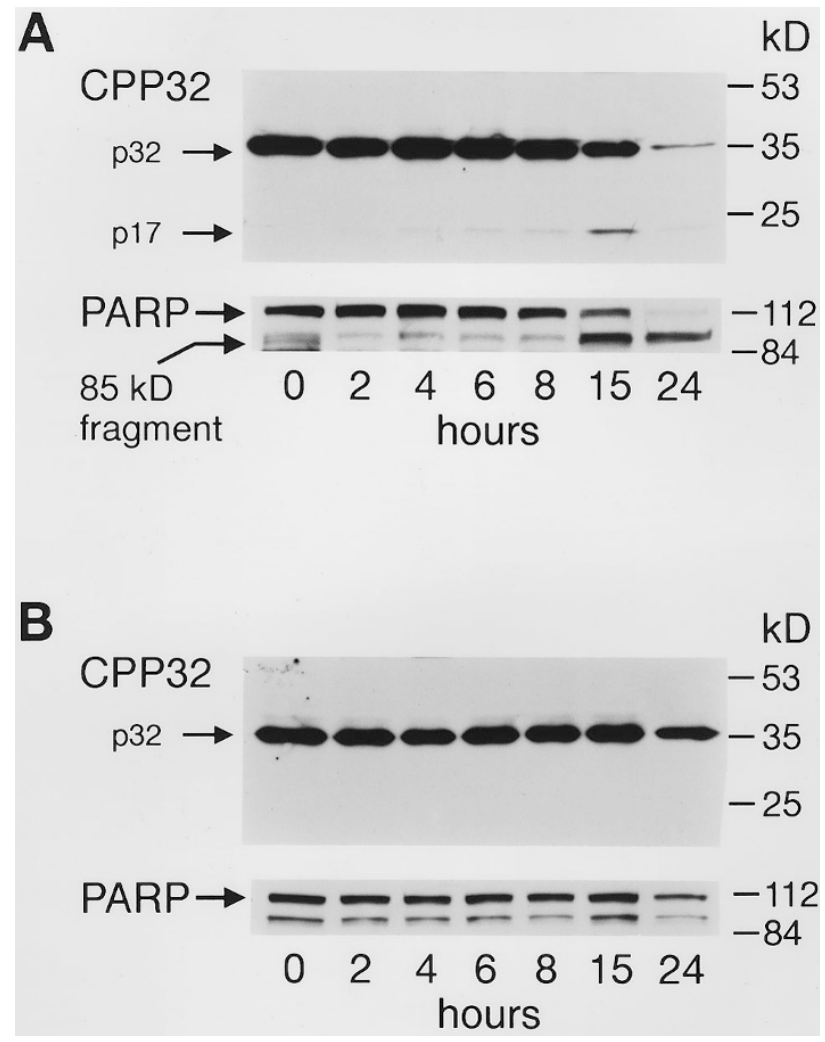

Figure 3 CPP32 and PARP activation in control and $\mathrm{Bcl}-2$ overexpressing HeLa cells. Control (A) and Bcl-2 overexpressing HeLa cells (B) were exposed for different times to $1 \mu \mathrm{M}$ staurosporine. Cells were then lysed directly in sample buffer. Lysates from $10^{6}$ cells were electrophoresed on a reducing $4-$ $20 \%$ SDS-polyacrylamide gel and proteins were then transferred by electroblotting on to nitrocellulose membranes. CPP32 and PARP were detected with appropriate antibodies.

around $85 \mathrm{kD}$ which may correspond either to the $85 \mathrm{kD}$ fragment of PARP, or to a non specific band. The first possibility would suggest the presence of a constitutive level of PARP proteolysis in cultured HeLa cells. The important result to note in these experiments was the reduction in the level of the $116 \mathrm{kD}$ fragment in normal cells treated with staurosporine for $15 \mathrm{~h}$. This disappearance was almost complete by $24 \mathrm{~h}$ and was accompanied by a strong increase in intensity of the $85 \mathrm{kD}$ band (Figure $3 \mathrm{~A}$ ). This demonstrates, in agreement with previous studies using other cell types (Tewari et al, 1995; Lazebnik et al, 1994), that PARP is converted to the $85 \mathrm{kD}$ fragment during PCD. Cleavage of PARP was inhibited by $\mathrm{Bcl}-2$ overexpression (Figure $3 \mathrm{~B}$ ). Indeed, after a $24 \mathrm{~h}$ staurosporine exposure, levels of PARP contained in $\mathrm{Bcl}-2$-overexpressing cells were similar to those of untreated cells. Also in these cells, the $85 \mathrm{kD}$ band detected in untreated cells did not increase when cells were exposed to the compound.

In addition to PARP, we examined the status of the U1$70 \mathrm{kD}$ small ribonucleoprotein by immunoblotting and immunocytochemistry (Figure 4A-E). U1-70K has been reported to be cleaved, probably by an ICE-like protease, into a fragment of 40-kD during apoptosis (Casciola-Rosen et al, 1994; Tewari et al, 1995). Immunoblotting of HeLa cell extracts with a mouse monoclonal antibody to U1-70K revealed a band migrating at around $70 \mathrm{kD}$ (Figure 4A). A significant decrease in the intensity of this band was found after $15 \mathrm{~h}$ of treatment with staurosporine. In Bcl-2 overexpressing cells, this decrease in U1-70 kD levels did not occur. Immunocytochemistry studies revealed that all cells displayed a speckled-labeling pattern which is in agreement with previous reports (Spector et al, 1992) (Figure 4B). In almost all control cells cultured in the presence of staurosporine for $8 \mathrm{~h}$, the staining had disappeared (Figure 4D). However, a small percentage of cells displayed a strong nuclear staining with a pattern totally different from that observed in cells cultured in normal conditions (Figure 4C). It was composed of two or three intensely labeled large dots. A Hoechst staining revealed that the morphology of these nuclei as well as that of cells lacking U1-70K was less homogenous than normal, but as yet was not condensed (Figure 4E). Hoechst staining also showed that the large dots did not contain DNA. In Bcl-2-overexpressing cells the pattern staining of U1-70K did not change after staurosporine treatment (not shown).

\section{Conclusion}

To date many members of the ICE gene family have been identified but, as yet, very little is known about their role in PCD. Here we have shown that CPP32 is processed during PCD in HeLa cells undergoing staurosporine-triggered apoptosis. We have evidence that CPP32 is also activated in FAS-mediated cell death (Chinnaiyan et al, 1996; our unpublished data). This suggests that CPP32 could be an effector common to many PCDs. Recently, a new protease of the ICE gene family, named ICE-LAP3 has been identified and found to be activated during FAS and TNF-mediated PCD (Duan et al, 1996). This protease is highly homologous to CPP32 and it is not clear yet whether it acts in the same or in a different pathway. ICE (Hogquist et al, 1991), ICE-LAP3 and CPP32 are, today, the only proteases known to be activated during PCD. Activation of CPP32 in staurosporine-induced apoptosis, like that of ICE-LAP3 for cytokine-mediated cell death, precedes the characteristic changes in cellular morphology, such as nuclear condensation. Interestingly, in our experiments, we found that proteolysis of PARP and U1$70 \mathrm{~K}$ proteins was concomitant with CPP32 activation. This suggests, but does not prove, that CPP32 is responsible, directly or indirectly, for cleavage of these proteins. Concerning proteolysis of U1-70K, it was striking to note that loss of detection of the protein in the nucleus was preceded by a change in the pattern of nuclear staining. Disappearance of $\mathrm{U} 1-70 \mathrm{~K}$ immunostaining is likely to be due to the lack of immunoreactivity of the antibody against the cleaved fragments of the protein. Indeed by Western blotting the antibody was unable to detect the previously described $40 \mathrm{kD}$ proteolytic fragment (Casciola-Rosen et al, 1994; Tewari et al, 1995). U1-70K immunostaining also confirmed that during apoptosis, the nucleus is the place of profound structural changes since the staining pattern of the protein was changed from a fine punctate staining to globular dots. We have also evidences that subnuclear domains, including 

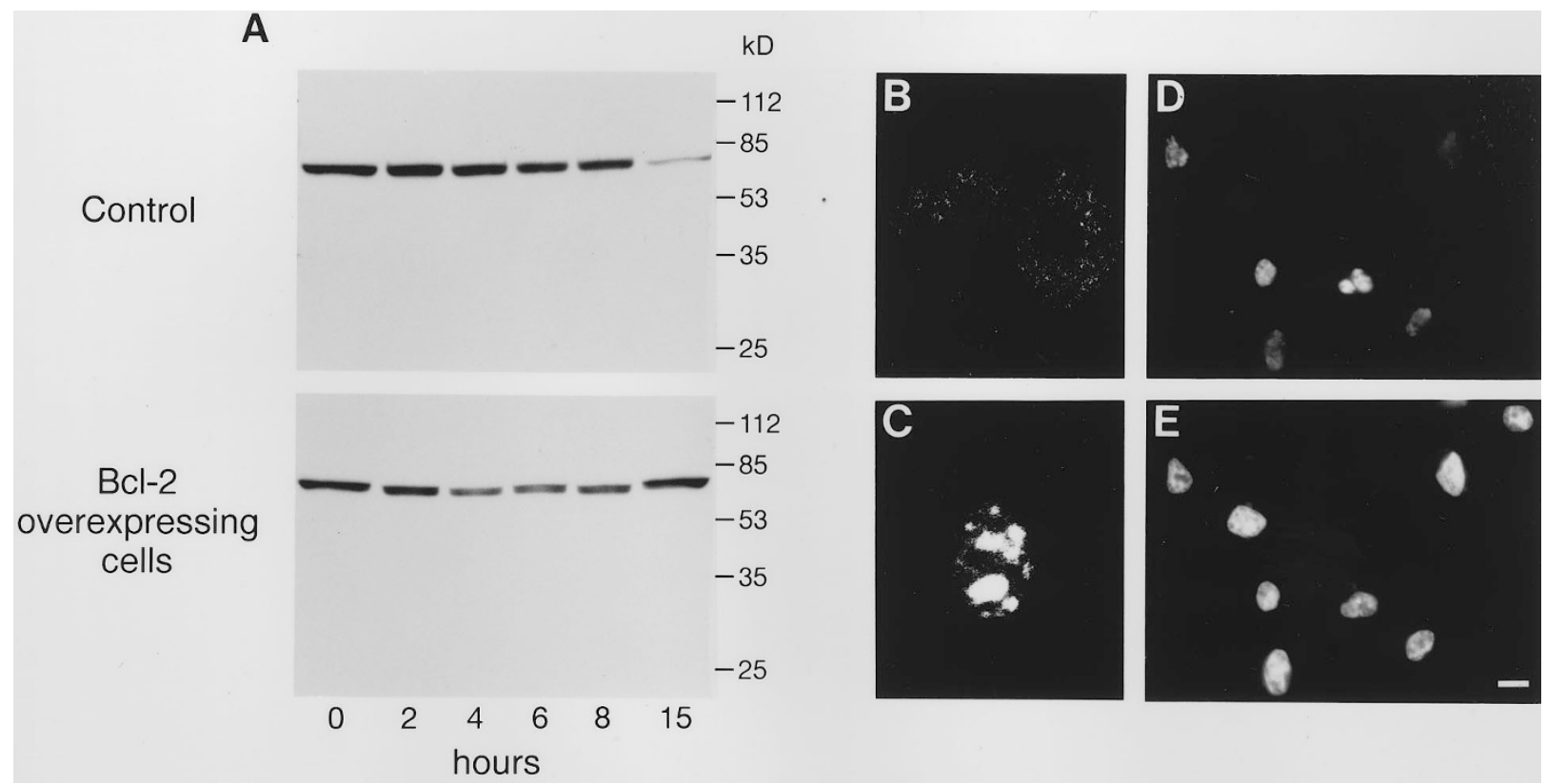

Figure 4 U1-70K cleavage (A) Western blot analysis of U1-70K Equal amounts of proteins from HeLa cells cultured in the presence of staurosporine were processed for Western blot analysis of U1-70K as described in Figure 3. The protein was detected by means of a mouse monoclonal to recombinant U1-70K. (B-E) Immunofluorescence localization of U1-70K in HeLa cells treated with or without staurosporine. (B) Untreated HeLa cells display a speckled-labeling nuclear pattern; the cytoplasm does not stain. (C) Control HeLa cells treated for $15 \mathrm{~h}$ with staurosporine: note that the staining reveals large nuclear bright dots. (D-E) View of a field containing several cells treated for $15 \mathrm{~h}$ with staurosporine. Note the difference in the intensity of U1-70K staining between cells (D). (E) Hoechst staining reveals that U1-70K negative cells display a nucleus which as yet is not condensed. Bar is $7 \mu \mathrm{m}$ for $\mathbf{B}, \mathbf{C}$ and $30 \mu \mathrm{m}$ for $\mathbf{D}, \mathbf{E}$.

coiled bodies, are affected during staurosporine-induced PCD (unpublished data). Whether these structural modifications are specific to staurosporine or are events common to all PCD needs further investigations.

In this paper, we have also shown, in agreement with published data from other laboratories (Enari et al, 1995; Martin et al, 1995; Chinnaiyan et al, 1996), that overexpression of $\mathrm{Bcl}-2$ prevents activation of CPP32 and proteolysis of PARP and U1-70K. Bcl-2 overexpression can block some, but not all, of the pathways leading to PCD. For example, Bcl-2 seems to provide little protection against FAS/APO-1 transduced apoptosis in lymphocytes (Strasser et al, 1995). In contrast, CrmA a potent inhibitor of ICE, and probably of other members of the family when overexpressed, confers protection to these cells. These results demonstrate that the mechanism of protection conferred by $\mathrm{Bcl}-2$ is not the same to that conferred by inhibitors of the ICE family. The mechanisms by which Bcl2 achieves protection remains to be elucidated.

\section{Materials and Methods}

\section{Establishment of stable HeLa cell lines that constitutively overexpress Bcl-2}

Human Bcl-2 cDNA was excised from the PGK-bcl-2 construct described by Martinou et al (1994) with Sfil, blunt ended and inserted into a neomycine resistance containing plasmid under the control of phosphoglycerate kinase promoter. HeLa cells were transfected with either the empty plasmid vector or with the plasmid encoding $\mathrm{Bcl}-2$ by a calcium phosphate procedure (Promega). Pools of stably transfected cells were selected in media containing G418. The cell pools were grown in DMEM, $10 \%$ FCS and $0.4 \mathrm{mg} / \mathrm{ml} \mathrm{G} 418$ and subjected to staurosporine. Cell viability was measured as described in (Jacobson et al, 1993, 1994).

\section{Immunocytochemistry}

Human $\mathrm{Bcl}-2$ was detected using a monoclonal antibody to human Bcl2 (Cambridge Research Biochemicals) as previously described (Martinou et al, 1994).

\section{Western blot analysis}

Mouse monoclonal antibody to CPP32 was purchased from Transduction Laboratories. This antibody was made against the first 219 amino-acids of CPP32. Polyclonal and monoclonal antibodies to PARP and U1-70K respectively have been described previously (Schreiber et al, 1995; Nelissen et al, 1994). Whole cell lysates were resolved by SDS-PAGE, transferred to nitrocellulose, and processed for immunoblotting. Both antibodies were used at a dilution of 1:1000. Peroxidase-labeled goat anti-mouse and goat anti-rabbit antibodies (Dako, DK) were used as secondary antibodies. The ECL detection system (Amersham) was used to develop blots.

\section{Acknowledgements}

We are grateful to Dr. Walter J. van Venrooij and Dr. Gilbert de Murcia for kindly providing anti-U1-70K and anti-PARP antibodies respectively and Drs. Jonathan Knowles, Kinsey Maundrell and Pierre Vassalli for helpful comments and for reading the manuscript. We thank Christoph Hebert for help in preparing the figures. 


\section{References}

Bump NJ, HackettM, Hugunin M, Seshagiri S, Brady K, Chen P, Ferenz C, Franklin S, Ghayur T, Li P, Licari P, Mankovich J, L.Shi, Greenberg AH, Miller LK and Wong WW (1995) Inhibition of ICE family proteases by baculovirus antiapoptotic protein P35. Science 269: 1885-1888

Casciola-Rosen LA, Miller DK, Anhalt GJ and Rosen A (1994) Specific cleavage of the $70-\mathrm{kDa}$ protein component of the $\mathrm{U} 1$ small nuclear ribonucleoprotein is a characteristic biochemical feature of apoptotic cell death. J. Biol. Chem. 269: 30757-30760

Chinnaiyan AM, Orth K, O'Rourke K, Duan H, Poirier GG and Dixit VM (1996) Molecular ordering of the cell death pathway. J. Cell. Biol. 271: 4573-4576

Duan H, Chinnaiyan M, Hudson PL, Wing JP, HeW-W and Dixit VM (1996) ICE-LAP3, a novel mammalian homologue of the Caenorhabditis elegans cell death protein $\mathrm{Cd}-3$ is activated during Fas- and Tumor Necrosis Factor-induced apoptosis. J. Biol. Chem. 271: $1621-1625$

Ellis RE, Yuan J and Horvitz HR (1991) Mechanisms and functions of cell death. Annu. Rev. Cell Biol. 7: 663-698

Enari M, Hase A and Nagata S (1995) Apoptosis by a cytosolic extract from Fasactivated cells. EMBO: 14: 5201-5208

Faucheu C, Diu A, Chan AW, Blanchet AM, Miossec C, Herve F, Collard-Dutilleul V, Gu Y, Aldape RA, Lippke JA, Rocher C, Su M, Livingston DJ, Hercend T and Lalanne JL (1995) A novel human protease similar to the interleukin-1 beta converting enzyme induces apoptosis in transfected cells. Embo J. 14: 19141922

Fernandes-Alnemri T, Litwack G and Alnemri ES (1994) CPP32, a novel human apoptotic protein with homology to Caenorhabditis elegans cell death protein Ced-3 and mammalian interleukin-1 beta-converting enzyme. J. Biol. Chem. 269: $30761-30764$

Fernandes-Alnemri T, Litwack G and Alnemri ES (1995) Mch2, a new member of the apoptotic Ced-3/lce cysteine protease gene family. Cancer Res. 55: 2737-2742

Jacobson MD, Burne JF, King MP, Miyashita T, Reed JC and Raff MC (1993) Bcl-2 blocks apoptosis in cells lacking mitochondrial DNA. Nature 361: 365-369

Jacobson MD, Burne JF and Raff MC (1994) Programmed cell death and Bcl-2 protection in the absence of a nucleus. EMBO J. 13: 1899-1910

HogoquistKA, Nett MA, Unanue ER and Chaplin DD (1991) Interleukin 1 is processed and released during apoptosis. Proc. Natl. Acad. Sci. USA 88: 8485-8489

Kamens J, Paskind M, Hugunin M, Talanian RV, Allen H, Banach D, Bump N, Hackett M, Johnston CG, Li P, Mankovich JA, Terranova M and Ghayer T (1995) Identification and characterization of $\mathrm{ICH}-2$, a novel member of the interleukin-1 beta-converting enzyme family of cysteine proteases. J. Biol. Chem. 270: $15250-15256$

Kaufmann SH, Desnoyers S, Ottaviano Y, Davidson NE and Poirier GG (1993) Specific proteolytic cleavage of poly(ADP-ribose) polymerase: an early marker of chemotherapy-induced apoptosis. Cancer Res. 53: 3976-3985

Kumar S and Harvey NL (1995) Role Of Multiple Cellular Proteases In the Execution Of Programmed Cell Death. Febs Lett. 375: 169

Kumar S, Kinoshita M, Noda M, Copeland NG and Jenkins NA (1994) Induction of apoptosis by the mouse Nedd2 gene, which encodes a protein similar to the product of the Caenorhabditis elegans cell death gene ced-3and the mammalian IL-1 $\beta$-converting enzyme. Genes and Develop. 8: 1613-1626

Lazebnik YA, Kaufmann SH, Desnoyers S, Poirier GG and Earnshaw WC (1994) Cleavage of poly(ADP-ribose) polymerase by a proteinase with properties like ICE. Nature 371: 346-347
Martin SJ, and Green DR (1995) Protease activation during apoptosis: death by a thousand cuts? Cell 82: $349-352$

Martin SJ, Newmeyer DD, Mathias S, Farshon DM, Wang H-G, Reed JC, Kolesnick RN and Green D.R. (1995) Cell-free reconstitution of Fas-, UV radiation and ceramide-induced apoptosis. EMBO J. 14: 5191-5200

Martinou JC, Dubois-Dauphin M, Staple JK, Rodriguez I, Frankowski H, Missotten M, Albertini P, Talabot D, Catsicas S, Pietra C and Huarte J (1994) Overexpression of $\mathrm{BCL}-2$ in transgenic mice protects neurons from naturally occurring cell death and experimental ischemia. Neuron 13: 1017-1030

Miura M, Zhu H, Rotello R, Hartwieg EA and Yuan J (1993) Induction of apoptosis in fibroblasts by IL- $1 \beta$ converting enzyme, a mammalian homolog of the $C$. elegans cell death gene ced-3. Cell 75: 653-660

Munday NA, Vaillancourt JP, Ali A, Casano FJ, Miller DK, Molineaux SM, Yamin TT, Yu VL and Nicholson DW (1995) Molecular cloning and pro-apoptotic activity of ICErelll and ICErellII, members of the ICE/CED-3 family of cysteine proteases. J. Biol. Chem. 270: 15870-15876

Nelissen RL, Will CL, van Venrooij WJ and Luhrmann R(1994) The association of the U1-specific 70K and C proteins with U1 snRNPs is mediated in part by common U snRNP proteins. Embo J. 13: 4113-4125.

Nicholson DN, Ali A, Thornberry NA, Vaillancourt JP, Ding CK, Gallant M, Gareau Y, Griffin PR, Labelle M, lazebnik YA, Munday NA, Raju SM, Smulson ME, Yamin TT, Yu VL and Miller DK (1995) Identification and inhibition of the ICE/ CED-3 protease necessary for mammalian apoptosis. Nature 376: $37-43$

Oltvai ZN and Korsmeyer SJ (1994) Checkpoints of dueling dimers foil death wishes [comment]. Cell 79: 189-192

Reed JC (1994) Bcl-2 and the regulation of programmed cell death. J. Cell. Biol. 124: $1-6$

Schreiber V, Hunting D, Trucco C, Gowans B, Grunwald D, De Murcia G and De Murcia JM (1995) A dominant-negative mutant of human poly(ADP-ribose) polymerase affects cell recovery, apoptosis, and sister chromatid exchange following DNA damage. Proc. Natl. Acad. Sci. USA 92: 4753-4757

Spector DL, Lark G and Huang S (1992) Differences in snRNP localization between transformed and nontransformed cells. Mol. Biol. Cell. 3: 555-569

Strasser A, Harris AW, Huang DCS, Krammer PH and Cory S (1995) Bcl-2 and Fas Apo-1 regulate distinct pathways to lymphocyte apoptosis. Embo J. 4: 6136

Tewari M, Beidler DR and Dixit VM (1995) CrmA-inhibitable cleavage of the 70-kDa protein component of the U1 small nuclear ribonucleoprotein during Fas- and tumor necrosis factor-induced apoptosis. J. Biol. Chem. 270: 18738-18741

Wang L, Miura M, Bergeron L, Zhu H and Yuan J (1994) Ich-1, an Ice/ced-3-related gene, encodes both positive and negative regulators of programmed cell death. Cell 8: $739-750$

Wang X, Pai J-T, Wiedenfeld EA, Medina JC, Slaughter CA, Goldstein JL and Brown MS (1995) Purification of an interleukin-1 $\beta$ converting enzyme-related cysteine protease that cleaves sterol regulatory element-binding proteins between the leucine zipper and transmembrane domains. J. Biol. Chem. 270: 18044-18050

Xue D and Horvitz HR (1995) Inhibition of the Caenorhabditis elegans cell-death protease CED-3 by a CED-3 cleavage site in baculovirus p35 protein. Nature $377: 248-251$

Yuan J (1995) Molecular control of life and death. Curr. Opin. Cell. Biol. 7: 211-214 